Article

\title{
Analysis of Farmer's Choices for Climate Change Adaptation Practices in South-Western Uganda, 1980-2009
}

\author{
Alex Zizinga ${ }^{1, *}$, Richard Y. M. Kangalawe ${ }^{2}$, Andrew Ainslie ${ }^{3}$, Moses M. Tenywa ${ }^{1}$, \\ Jackson Majaliwa ${ }^{1,4}$, Naome Jones Saronga ${ }^{5}$ and Esther E. Amoako ${ }^{4}$ \\ 1 College of Agriculture and Environment Sciences, Makerere University, Kampala 7602, Uganda; \\ tenywamakooma@yahoo.com (M.M.T.); majaliwam@gmail.com (J.M.) \\ 2 Institute of Resource Assessment, University of Dar es Salaam, Dar es Salaam 35097, Tanzania; \\ rkangalawe@hotmail.com \\ 3 School of Agriculture, Policy \& Development, University of Reading, Reading RG66AR, UK; \\ a.m.ainslie@reading.ac.uk \\ 4 Department of Ecotourism \& Environmental Management, University for Development Studies, \\ Tamale 1350, Ghana; eamoako@uds.edu.gh \\ 5 School of Public Health and Social Sciences, Muhimbili University, Dar es Salaam 65001, Tanzania; \\ nsaronga@gmail.com \\ * Correspondence: azizinga@caes.mak.ac.ug; Tel.: +256-77-4284497
}

Received: 7 August 2017; Accepted: 25 October 2017; Published: 2 December 2017

\begin{abstract}
Climate change is a serious threat to the livelihoods of rural communities, particularly in mountainous areas because they are very sensitive to such changes. In this study, we assessed the household determinants to climate change adaptation drawing from a case study of agricultural adaptation in the Mount Rwenzori area of South Western Uganda. The study identified the major adaptation practices that are adopted by farmers to cope with the impacts of climate change and using available on-farm technologies. A total of 143 smallholder farmers were sampled and interviewed using field based questionnaires, field observations, and key informant interviews. Data was cleaned, entered and analysed using SPSS and Stata software for descriptive statistics. Thereafter, a Multinomial logistic regression model was used to assess the drivers of farmers' choice for adaptation practices, factors influencing the choice of adaptation, and barriers. The major adaptation practices that were identified included; use of different crop varieties, tree planting, soil and water conservation, early and late planting, and furrow irrigation. Discrete choice model results indicated the age of the household head, experience in farming, household size, climate change shocks, land size, use of agricultural inputs, landscape position (location), and crop yield varied significantly $(p>0.05)$, which influenced farmers' choice of climate change adaptation practices. The main barriers to adaptation included inadequate information on adaptation methods and financial constraints, leading us to conclude that contextual adaptation practices are more desirable for adoption to farmers. Adapting to climate change needs support from government and other stakeholders, however the implementation is more successful when appropriate and suitable choices are employed.
\end{abstract}

Keywords: climate change; small-holders; adaptation practices; Albertine Graben-Uganda

\section{Introduction}

Globally, there has been an increased focus on sustainable adaptation and mitigation practices for climate change impacts in various communities. This emanates from severe weather occurrences and substantial evidence of changes in climate that require people to adapt for a sustainable livelihood. The current changes in the essential climate variables (atmospheric, oceanic, and terrestrial) have 
contributed to adverse climatic outcomes in many parts of the world [1,2], and this has illustrated the importance of implementing climate change adaptation practices [3].

It is now well established that changes in climate are affecting smallholder farmers and threatening farming livelihoods in Sub-Saharan Africa [4]. The present adverse changes in climate that have manifested globally have emphasised the need to identify and better understand possible adaptation to cope with climatic impacts. Alterations in the global climate system are often seen in modes of prolonged drought spells, and marked variations in temperature [5,6]. Multiple studies have now identified the myriad instances where climate change impact on ecosystems, livelihoods, and human development [7-9]. The prolonged drought spells and floods pose a risk to natural resource management in the form of biomass loss and runoff [9-11], and consequently, these affect the agricultural sector. Agricultural production and global food security are directly affected by global warming [12-15]. Sudden increases in temperature results in moisture loss and has multiple knock-on effects on people's basic livelihood enterprises, which causes great uncertainty [16]. This is more apparent in Sub-Saharan Africa, especially where a strong dependence on rainfed agriculture predominates and is already adversely affected by climatic changes [17]. In a country like Uganda, where agriculture supports over $70 \%$ of the people, this is a real cause for concern [18].

The agricultural sector in Uganda, which is dominated by small scale and mixed-crop systems, is the dominant sector of the economy. This sector contributes enormously to the country's gross domestic product at $70 \%$ and the agro-enterprise sector provides $75 \%$ of employment to the national workforce [18]. However, agriculture suffers from droughts as a result of decline and variability of rains, which contribute to hunger and the death of livestock. It is therefore important to prepare the country with possible adaptation practices to avoid economic shocks emanating from the agriculture sector $[19,20]$.

Among smallholder farmers, the drivers of climate change adaptation are linked in complex interdependences that relate to perceptions of changing climatic conditions, agricultural productivity, and the socio-ecological adaptation practices that are employed at a household level. Decision-making at the household and community levels is critical in buffering the adverse impacts of climate variability and change. Knowledge of the constraints and perceived opportunities in relation to this decision-making can guide the formulation of new and/or propose adjustments in existing practices and policy options that are site specific and reliable to sustain and protect the communities through continued production systems, which are more resilient to the vagaries of weather.

Other factors like economic and institutional considerations are also key in understanding the determinants of farmers' choices to adaptation in climate-related changes and how to direct policy formulation and appropriate investment in implementation to the agricultural sector [21]. Numerous studies [22,23] have identified adaptation strategies and the factors hindering the implementation of adaptation across different climate shocks. However, a socio-economic assessment on what determines the capacity and drive to adapt presents a missing link to increase adoption of climate change adaptation practices among smallholder communities. In this study, a driver is any natural or human-induced factor that directly or indirectly causes a change that manifests in adoption of a practice.

In the south-western Ugandan part of the Albertine, farming communities are very vulnerable to climatic changes. Increases in temperatures over the past thirty years and low rains, as indicated in the temperature trend graph below, illustrate a fundamental problem for farmers seeking to maximize seasonal farm yield, hence a decline in yields and a decrease in household incomes. Other barriers, like a lack of information, lack of finances to adopt improved technology, lack of irrigation, and shortage of labour are key limiting factors to cope and adapt with climate change in the study area. Nevertheless, despite these problems, smallholder farmers in the study area have deployed different adaptation practices that can influence the productivity based on the following key factors; soil conservation, crop variety, change in planting dates, tree planting/agroforestry, and furrow irrigation. 
The continuous on-farm practices, which farmers adjust on a seasonal basis to cope with climatic changes with an aim of improving yield and their land productivity, are referred to as sustainable adaptation in this study. These practices are location specific, controlled by policy frameworks, have a temporal aspect, are dependent on the dynamism of farmers, and their choice is influenced by multiple drivers. Despite the multiple functions of adaptation to smallholder farmers, there are limited studies that have focused on an assessment of the key drivers influencing the adoption of adaptation practices for climate change in the Albertine rift of Uganda. On one hand, the use of adaptation practices and actions are often portrayed as re-active for immediate response to climate change occurrences, which are imposed without understanding the past environmental characteristics of an area. For example, in cases of droughts and floods, there are often immediate measures taken by the authorities and others to reinstate an 'equilibrium' within that environment. Also, the higher level institutions are assumed to plan in an anticipatory manner for adaptation through formulating policies, suggesting adaptation programs, such as Climate Smart Agriculture, and most recently, through the National Adaptation Plans of Action (NAPAs). The NAPAs have for the most part been developed by countries with limited attention being given to the determining factors, which will drive farmers' decision-making around implementation [24]. As a result, therefore, smallholder farmers are practicing various adaptation strategies, including sub-optimal ones, on their farms, with the choice of the adaptation strategies that are known to be influenced by various factors including; Sex, Age, Experience of farming, Household size (members living in a household), Membership (Group affiliation of members), Shock floods, Land size, Farm inputs, Landscape position, Level of Education, Crop yield, and Farm income [25-31]. This study investigates how these drivers influence farmers' decision-making in relation to climate change adaptation. Understanding the relative importance of these factors will help farmers to easily employ viable adaptation practices and to overcome famine and major crop production constraints.

\section{Methodology}

\subsection{The Study Area}

This study was carried out in Kasese district (Figure 1), located in the Albertine graben, in the Mount Rwenzori area in the south-western region of Uganda (Albertine rift), which is astride the equator. The data was collected from key informants, and a household survey comprising of femaleand male-headed households, the youth and elderly. Other participants were agriculture extension workers, environment officers, and district agriculture production officers, using semi-structured questionnaires that were administered to 143 respondents from a proportionate stratified random sampling, which contributed to the total number of households. These households were selected for the study based on landscape position where farmers live (upper, middle, and lower slopes).

The sample size was determined from the total population of 18,538 households and was calculated using the formula proposed by Yamane [32,33], where $\mathrm{n}=$ Sample size, $\mathrm{N}=$ Total number of households for the study area, and $\alpha=$ marginal of error set at $10 \%$ and the sample size derived was 99.46. The data was edited, coded, and entered into SPSS version 17.0 and Stata statistic software package for descriptive and inferential statistics performed on the data obtained from the questionnaires. Descriptive statistical tools included percentages, frequencies, and standard deviations. These statistics were also used to analyze data on demographic, physical, and socio-economic characteristics of households in the area. The explanatory variables in the study included; Sex, Age, Experience of farming, Household size (members living in a household), Membership (Group affiliation of members), Shock floods, Land size, Farm inputs, Landscape position, Level of Education, Crop yield, and Farm income. The dependent variables included; crop varieties, changing planting dates, planting trees/agroforestry, furrow irrigation, and soil conservation practices. However, when all were entered in Stata software, they were not all statistically significant as illustrated in the results of the study below. 


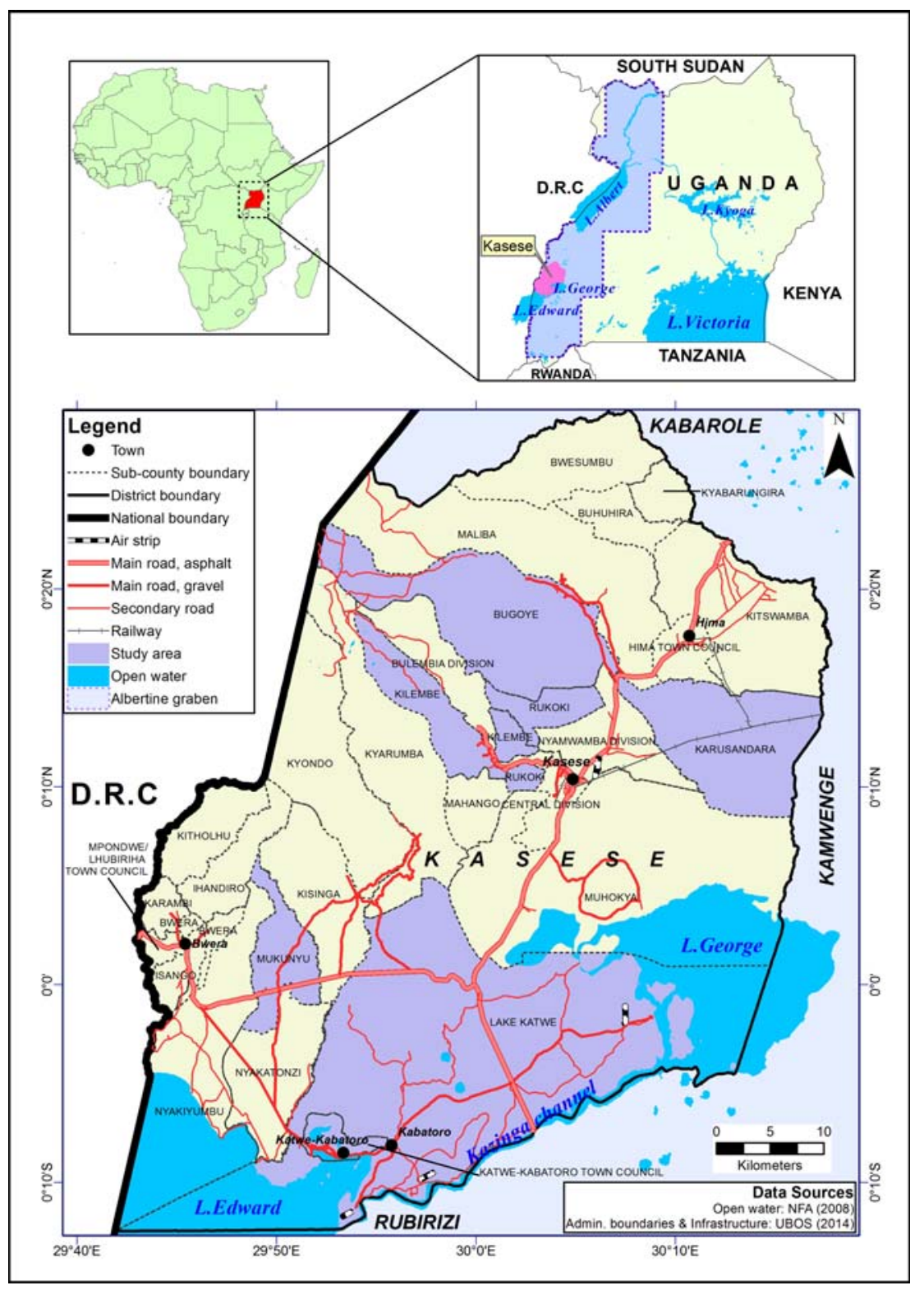

Figure 1. Map of the study area.

Using Stata statistic software package, a multinomial logit regression model was used to assess the choice and factors influencing adoption of farmers' adaptation practices [34]. According to [35,36], this method is well-suited to assess and analyze crop and livestock for a given environment. The model is widely used by different researchers to analyze the determinant factors that affect the choice of households' adaptation measures to climate variability performing, with more than two outcomes of the dependent variable [37-39]. The study has dependent variables and adaptation with more than two outcomes such as soil conservation practices, changing planting dates, trees/agroforestry and furrow irrigation.

\subsection{Climate Data Analysis of the Study Area}

Climate data for the study area covering the years 1980-2010 was obtained from the Meteorological Department of Uganda. The data was cleaned, converted to a Log10 base for autocorrelation, and analyzed using Genstat discovery to characterize the variability and trends in amount and distribution of rainfall and temperature pattern of the study area as indicated in Figure 2. 


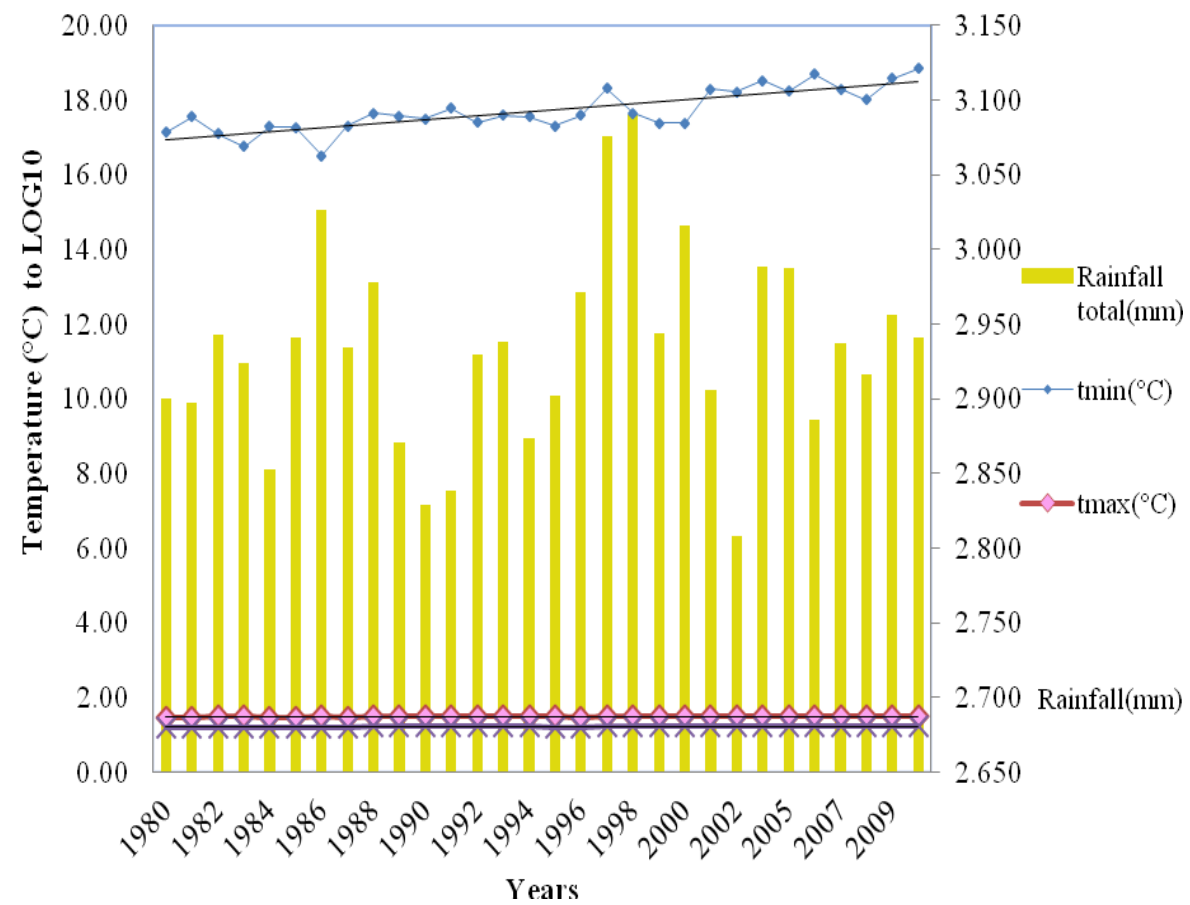

Figure 2. Temperature trends for Kasese district.

\section{Results}

The majority of the respondents perceived an increase and decrease in precipitation and temperature respectively in the study area. The descriptive statistics illustrate $46 \%$ increase in the temperature and $24 \%$ increase in the precipitation over the period in question (Table 1). For each of the farmers interviewed, there was at least one of the following adaptation strategies that were employed on their farms; different crop varieties, changing planting dates, planting trees/agroforestry, use of furrow irrigation, and soil conservation practices.

Table 1. Perceptions of precipitation and temperature changes among farmers.

\begin{tabular}{cc}
\hline Climatic Variable & Number and Percentage of Respondents \\
\hline (a) Temperature & \\
\hline Temperature increased & $\mathrm{N}=66(46 \%)$ \\
Temperature decreased & $\mathrm{N}=6(4 \%)$ \\
Temperature stayed the same & $\mathrm{N}=25(17 \%)$ \\
\hline (b) Precipitation & \\
\hline Precipitation increased & $\mathrm{N}=34(24 \%)$ \\
Precipitation decreased & $\mathrm{N}=2(1 \%)$ \\
Precipitation stayed the same & $\mathrm{N}=10$ \\
\hline Total number of respondents & $\mathrm{N}=\mathbf{1 4 3 ( \mathbf { 1 0 0 } \% )}$ \\
\hline
\end{tabular}

\subsection{Weather Trends and Time Series Data for Climatic Changes Detection in the Study Area}

Since 1980-2009, the average surface temperature across the region changed from a maximum of $30{ }^{\circ} \mathrm{C}$ to $32{ }^{\circ} \mathrm{C}$ (Figure 2). The equation in Figure $2(y=0.0451 \mathrm{x}+23.372)$ illustrates a change in mean temperature over time and $\mathrm{R}^{2}=0.7332$ indicating that $73.3 \%$ of the total variation in temperature 
(y) has a linear relationship between $\mathrm{x}=$ years and $\mathrm{y}=$ temperature (as described by the regression equation). Therefore, there is a significant change over the 30 years in the average temperature implying occurrences in climatic changes. This average temperature has risen more quickly since the late 1960s, shifting weather patterns and causing more extreme climate events, which are currently affecting the society and ecosystems. For example, in the period of 1997 to 1998, as illustrated in Figure 2, there were El Nino rains ranging between $1200 \mathrm{~mm}$ to $1400 \mathrm{~mm}$, which affected the lowlands in the study area with floods spreading in Karusandara sub-county, Kasese district.

In the past 30 years, farmers who experienced and observed changes in climate (Figure 2) were subsequently probed on how they employed adaptation practices to buffer climate change impacts. Also, in the process of adaptation, various barriers affect communities to practice and implement adaptation programs in their major livelihood enterprises as illustrated (Figure 3);

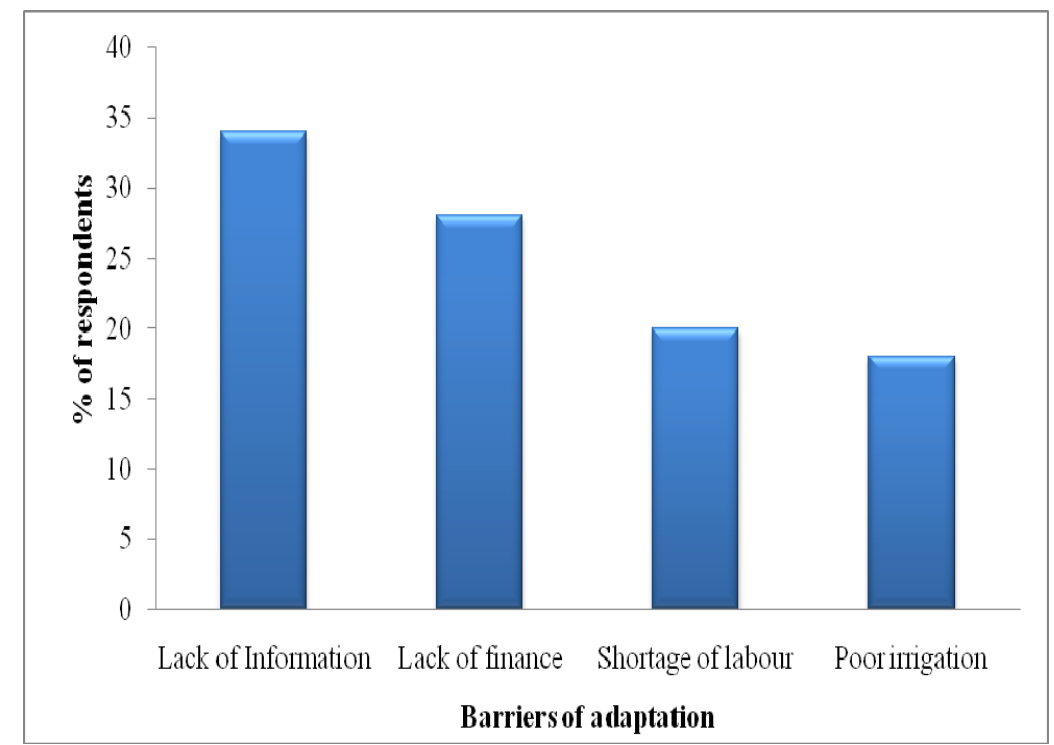

Figure 3. Barriers to adoption of climate change adaptation.

Crops grown in the study area differed according to the landscape position, as indicated in Figure 4, depending on the favourable soils, climate, and elevation at a given location along the mountain slopes. In the upper slopes, banana and coffee were integrated with cassava, sweet potato, and maize. A similar intercropping strategy was also found in the mid slopes (1000-1450) and intercropped with annuals like maize, tomatoes, and a very small number of cotton. In the Mubuku Irrigation Scheme (mid-slope), farmers had adopted irrigated horticultural crops and improved maize varieties (Longe $6 \mathrm{H}$ maize) as a seasonal adaptation practice. During the field study, it was found out that agricultural land uses in Kasese also included the growing of perennial crops (banana and coffee) and annuals (beans, groundnuts, maize, sorghum, sweet potatoes, millet, cassava, Irish potato, and fruit trees). It was also revealed that these crops are grown at different locations along the mountain slopes (landscape positions), as illustrated in Figure 4. 


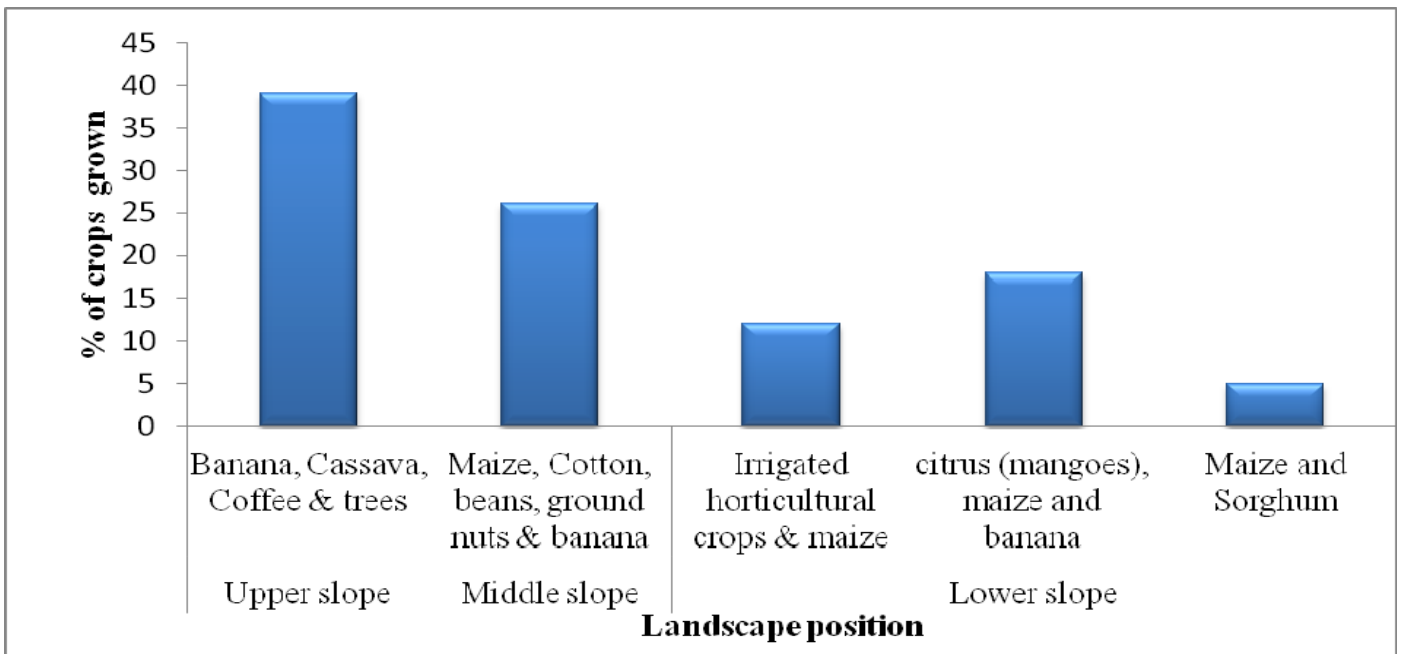

Figure 4. Crops grown in different Landscape positions within the study area.

\subsection{Empirical Model Results and Discussion}

In this paper, the multinomial logistic regression (MNL) choice model was employed to analyze the determinants of farmer adaptation practices in southwestern Uganda.

Model results for MNL indicating the drivers of using the different climate change adaptation practices are shown in Tables 2-6. For soil and water conservation, flood shocks and the existence of farm inputs were the most significant factors influencing their use. For crop variety, landscape position, crop yield, farm income, and household size were the most significant factors for use of new varieties. Change in planting date was influenced by drought shocks and their impacts, crop yield, farm income, and landscape position. Adoption of furrow irrigation was influenced by the age and experience of the farmer. Flood shocks negatively influenced the adoption of Soil Water and Conservation, while farm inputs had a positive effect. Only crop yield and household income had a positive effect on the adoption of crop variety and planting date, respectively. Drought shocks and landscape position had opposite effects in the adoption of tree planting/agroforestry. For furrow irrigation, experience had a negative effect while age had a positive effect, this is because smallholder farmers deploy irrigation as a new farm technology regardless to their experience and this is a government program implemented by the agricultural extension department for communities to adopt in the area.

Table 2. Parameter estimates of the multinomial logit model of drivers of adoption of soil conservation practices as climate change adaptation practice.

\begin{tabular}{cccc}
\hline Explanatory Variables & Coefficient & Standard Error & Marginal Effects \\
\hline Sex (Male and Female) & 0.306 & 0.987 & 0.26 \\
Age (Years) & 0.037 & 0.062 & 0.0003 \\
Experience of farming (Number of years) & -0.069 & 0.081 & -0.01 \\
Household size (members living in a household) & -0.441 & 0.302 & -0.038 \\
Membership (Group affiliation of members) & -1.69 & 1.501 & -0.196 \\
Shock floods & $-4.119 * *$ & 1.955 & -0.433 \\
Shock drought & -0.88 & 1.137 & -0.111 \\
Land size (Hectare) & 0.343 & 0.304 & 0.046 \\
Results of Shock & 1.639 & 1.125 & 0.23 \\
Use inputs (Farm inputs) & $1.461 *$ & 0.802 & 0.29 \\
Education (formal schooling) & -1.075 & 0.835 & 0.095 \\
Crop yield (Kilograms per hectare) & 0.388 & 0.93 & -0.009 \\
Farm income & -0.009 & 0.017 & -0.002 \\
\hline
\end{tabular}

* Significance at the $1 \%$ test level and ${ }^{* *}$ Significance at the $5 \%$ test level. 
Table 3. Parameter estimates of the multinomial logit of model for drivers of adoption of crop varieties as a climate change adaptation practice.

\begin{tabular}{|c|c|c|c|}
\hline Explanatory Variables & Coefficient & Standard Error & Marginal Effects \\
\hline Sex (Male and Female) & 0.690 & 1.11 & 0.093 \\
\hline Age (Years) & 0.068 & 0.074 & 0.006 \\
\hline Experience of farming (Number of years) & 0.058 & 0.092 & 0.013 \\
\hline Household size (members living in a household) & $-0.691 * *$ & 0.319 & -0.077 \\
\hline Membership (Group affiliation of members) & -1.97 & 1.538 & -0.256 \\
\hline Floods Shock & -1.369 & 1.936 & -0.166 \\
\hline Drought Shock & -0.839 & 1.25 & 0.036 \\
\hline Land size (hectares) & 0.32 & 0.347 & 0.002 \\
\hline Results of Shock & 0.421 & 1.17 & 0.066 \\
\hline Use inputs (Farm inputs) & -0.081 & 0.858 & -0.178 \\
\hline Landscape position (upper, middle, lower slopes) & $-1.785^{* *}$ & 0.878 & -0.206 \\
\hline Education (formal schooling) & 1.968 & 1.292 & 0.267 \\
\hline Crop yield (Kilograms per hectare) & 0.030 * & 0.017 & 0.005 \\
\hline Farm income & $-1.325 *$ & 0.799 & -0.178 \\
\hline
\end{tabular}

* Significance at the $1 \%$ test level; ** Significance at the $5 \%$ test level.

Table 4. Parameter estimates of the multinomial logit model of drivers of adoption of changing planting dates as a climate change adaptation practice.

\begin{tabular}{|c|c|c|c|}
\hline Explanatory Variables & Coefficient & Standard Error & Marginal Effects \\
\hline Sex (Male and Female) & 3.417 & 2.15 & $1.1 \times 10-7$ \\
\hline Age (Years) & 0.034 & 0.111 & $-3.10 \times 10^{-11}$ \\
\hline Experience of farming (Number of years) & -0.243 & 0.166 & $-4.23 \times 10^{-9}$ \\
\hline Household size (members living in a household) & 0.245 & 0.502 & $9.35 \times 10^{-9}$ \\
\hline Membership ( Group affiliation of members ) & 0.245 & 6.235 & $1.26 \times 10^{-7}$ \\
\hline Shock floods & 9.468 & 2.248 & $-1.82 \times 10^{-8}$ \\
\hline Shock drought & $-1.414^{* *}$ & 3.13 & $-7.97 \times 10^{-8}$ \\
\hline Land size (Hectare) & -6.213 & 0.586 & $-4.88 \times 10^{-9}$ \\
\hline Results of Shock & $-0.148^{* *}$ & 2.552 & -0.001 \\
\hline Use inputs (Farm inputs) & -5.024 & $9.6 \times 10^{7}$ & $-1.40 \times 10^{-7}$ \\
\hline Landscape position (upper, middle, lower slopes) & $-38.460^{* *}$ & 3.343 & $1.88 \times 10^{-8}$ \\
\hline Education (formal schooling) & 6.814 & 1.231 & $1.90 \times 10^{-8}$ \\
\hline Crop yield (Kilograms per hectare) & $-0.083 * *$ & 0.041 & $1.52 \times 10^{-9}$ \\
\hline Farm income & $8.942 * *$ & 4.435 & $1.74 \times 10^{-7}$ \\
\hline
\end{tabular}

** Significance at the $5 \%$ test level.

Table 5. Parameter estimates of the multinomial logit model of drivers of adoption of planting trees/agroforestry as climate change adaptation practice.

\begin{tabular}{|c|c|c|c|}
\hline Explanatory Variables & Coefficient & Standard Error & Marginal Effects \\
\hline Sex (Male and Female) & -1.143 & 1.735 & $-5.78 \times 10^{-8}$ \\
\hline Age (Years) & 0.206 & 0.143 & $7.62 \times 10^{-9}$ \\
\hline Experience of farming (Number of years spent) & -0.257 & 0.184 & $-1.07 \times 10^{-8}$ \\
\hline Household size (members living in a household) & 0.851 & 0.532 & $4.94 \times 10^{-8}$ \\
\hline Membership (Group affiliation of members) & 23.338 & 26.944 & $4.27 \times 10^{-6}$ \\
\hline Shock floods & 39.716 & $11,870.14$ & 0.9999 \\
\hline Shock drought & $14.934^{* *}$ & 7.112 & 0.004 \\
\hline Land size (Hectare) & -1.947 & 1.284 & $-9.22 \times 10^{-8}$ \\
\hline Results of Shock & -22.132 & $11,870.13$ & -0.104 \\
\hline Use inputs (Farm inputs) & 1.767 & 1.271 & $9.17 \times 10^{-8}$ \\
\hline Landscape position (upper, middle, lower) & $-14.173 * *$ & 6.46 & $-6.08 \times 10^{-7}$ \\
\hline Education (formal schooling) & 2.415 & 1.612 & $8.86 \times 10^{-8}$ \\
\hline Crop yield (Kilograms per hectare) & 0.057 & 0.038 & $2.43 \times 10^{-9}$ \\
\hline Farm income & 0.603 & 1.416 & $4.43 \times 10^{-9}$ \\
\hline
\end{tabular}


Table 6. Parameter estimates of the multinomial logit model of drivers of adoption of furrow irrigation as climate change adaptation practice.

\begin{tabular}{cccc}
\hline Explanatory Variables & Coefficient & Standard Error & Marginal Effects \\
\hline Sex (Male and Female) & -0.154 & 1.278 & -0.023 \\
Age (Years) & $0.227^{* *}$ & 0.112 & 0.014 \\
Experience of farming (Number of years) & $-0.205^{*}$ & 0.12 & -0.013 \\
Household size (members living in a household) & -0.59 & 0.46 & -0.024 \\
Membership ( Group affiliation of members ) & 1.605 & 3.758 & 0.098 \\
Shock floods & -0.365 & 2.269 & -0.051 \\
Shock drought & 0.55 & 1.537 & 0.068 \\
Land size (Hectare) & -0.185 & 0.369 & -0.021 \\
Results of Shock & 0.426 & 1.394 & 0.001 \\
Use inputs (Farm inputs) & -0.507 & 1.039 & -0.05 \\
Education (formal schooling) & -1.03 & 1.006 & -0.031 \\
Crop yield (Kilograms per hectare) & 0.199 & 1.036 & -0.017 \\
Farm income & -0.008 & 0.021 & -0.001 \\
\hline
\end{tabular}

* Significance at the $1 \%$ test level and ${ }^{* *}$ Significance at the $5 \%$ test level.

Shock floods were negatively related to the adoption of soil conservation practices as a climate change adaptation practice though being statistically significant $(p \leq 0.05)$. The results were contrary to expectation as farmers affected by shock floods were expected to adopt soil conservation practices. The occurrence of shock floods decreased the probability of adopting soil conservation practices by a factor of 0.433 .

The use of farm inputs showed a positive relationship to the adoption of soil conservation practices and was significant $(p \leq 0.01)$. This showed that farmers that used farm inputs like fertilizers, improved seeds, and herbicides, were more likely to take up soil conservation practices as compared to their counterparts. Farm inputs increased the probability of adopting soil conservation practices by a factor of 0.29 .

Household size was negative though statistically significant $(p \leq 0.05)$ to the adoption of crop varieties as a climate change adaptation practice. This indicated that if the size of the household increased by one member, the chance of adoption of different crop varieties reduced by a factor of 0.077 .

Landscape position was also negatively related to the adoption of crop varieties. However, it was statistically significant $(p \leq 0.05)$. The position of crop varieties on the upper, middle, or lower slopes decreased the probability of the adoption of crop varieties by a factor of 0.206 .

There was a positive and significant $(p \leq 0.01)$ relationship between crop yield and adoption of crop varieties as a climate change adaptation practice. Crop yield increased the probability of adopting crop varieties by a factor of 0.005 . This is because some crop varieties are drought, pest, and disease resistant, therefore the farmer does not incur losses to pests or diseases, something that leads to increased crop yield.

Farm income on the other hand, had a negative relationship with the adoption of crop varieties, although being statistically significant $(p \leq 0.01)$. A marginal effect of 0.178 indicated an increase in farm income by one unit deceased the odds of that household to adopt crop varieties by 0.178 .

The results revealed that shock drought was negatively related to the adoption of changing planting dates as a climate change adaptation practice, though being statistically significant $(p \leq 0.05)$. An experience with shock drought decreased the probability of adopting changing planting dates by 7.97.

Results of shock were also negatively related to the adoption of changing planting dates and this was also statistically significant $(p \leq 0.05)$.

Landscape position was also negatively related to the adoption of changing planting dates even though being statistically significant $(p \leq 0.05)$.

There was a negative relationship between crop yield and the adoption of changing planting dates, although the results were statistically significant $(p \leq 0.05)$. An increase in crop yield decreased the probability of adopting changing planting dates by a factor of 1.52 . 
Farm income showed a positive relationship to the adoption of changing planting dates and was statistically significant $(p \leq 0.05)$. An increase in the farm income increased the probability of adopting changing planting dates by a factor of 1.74 .

The relationship between shock drought and adoption of planting trees/agroforestry as a climate change adaptation practice was positive and statistically significant $(p \leq 0.05)$. The odds in favor of farmers who experienced shock drought increased by 0.004 as compared to those who did not experience shock drought. This implies that farmers who experience shock drought are more aware of its dangers and are therefore more willing to adopt mitigation strategies.

Landscape position however, had a negative relationship on the adoption of planting trees/agroforestry even though being statistically significant $(p \leq 0.05)$. Planting trees on a particular landscape position decreased the probability of adopting planting trees by a factor of 6.08 .

The age of the farmer showed a positive relationship to the adoption of furrow irrigation and was significant $(p \leq 0.05)$. This indicates that older farmers were more likely to adopt furrow irrigation as a climate change adaptation practice compared to their counterparts. Being older increased the probability of adopting furrow irrigation by a factor of 0.014 .

Experience in farming was negatively related to the adoption of furrow irrigation although being statistically significant $(p \leq 0.01)$. The marginal effect of 0.013 indicated that an increase in the farming experience by one unit decreased the odds of that household to adopt furrow irrigation.

\section{Discussion}

From the study results, it is clear that soil and water conservation is used by farmers to reduce soil erosion and degradation on their farms. This has a related aim of improving other biological farm practices, which include mulching and improved furrows. Although these methods are not sufficient to control soil erosion on farm, they do improve the soil structure especially when combined with mechanical methods of terracing, digging ditches, culverts, contour bunds, among others [40,41]. Adoption of these soil and water conservation (SWC) practices improves food security and the benefits associated with adaptation, for example, reducing soil erosion, increasing soil fertility, improving water management and water retention, which help farmers' soils to obtain and retain nutrients [42-44].

Other practices like agroforestry offer the possibility of increasing food security by allowing households to have a diversity of production avenues, which have potential for income enhancement. Agroforestry practices increase the absorptive capacity of soil [45]. (Blanco \& Lal, 2008) and reduce evapotranspiration [46], which can ameliorate the negative impacts of shortened growing seasons due to delayed onset of rain. The canopy cover from trees offer direct benefits by reducing soil temperature for crops that have been planted underneath. This increases the possibility of lowering the run off velocity and soil erosion due to heavy rainfall $[47,48]$.

\subsection{Flood Shocks}

The lowlands in the study area are vulnerable to floods during the rainy season which affects crops and therefore, adoption of Soil and Water Conservation practices is a driver for adoption to small holder farmers to both Gender though better implemented effectively with a given experience in farming. The Landscape position and the land terrain is also a major driver in adapting to flood shocks.

\subsection{Farm Inputs}

The farm inputs are adopted on a low rate, given the cost attached for purchase among the farmers; however, the driver is productive and high yield returns from their use. There is often a relative difference in the yield across farmers who use farm inputs like fertilizers and hybrid seed irrespective of Gender and Landscape position. 


\subsection{Use of New Varieties}

Various crop varieties and cultivars are adopted as drought resistant and high yielding to farmers in the slopes of mountain Rwenzori. New varieties of Maize like Longe 9H are some of the varieties adopted by farmers in the study area as a hybrid to cope with drought. This is a driver to cope with the prolonged droughts in any given season and its adoption is not influenced by Gender and Landscape position, but rather the yield returns and drought shocks is the major driver for adoption.

\subsection{Landscape Position}

The nature of the landscape position where farmers live along the slopes of mountain Rwenzori determines the adaptation practice to be implemented by farmers and the location of where farmers live and farm because different crops are grown across the middle slopes, upper slopes, and lower slopes (Figure 4). This is also associated with the Crops being cultivated in a particular area; for example, different adaptation practices in the Upper slopes, Middle slopes, and Lower slopes are subjected to different crops according to farmers experience in farming, age, and gender.

\subsection{Crop Yield}

The yield returns influence the adoption of several adaptation practices, like ability to purchase farm inputs, practice Soil and Water Conservation, and others. This is a key driver in the study area especially for Maize farmers, Coffee, Banana, and others across gender, size of the land, experience in farming, adoption of crop varieties and other agriculture innovations from farmer to farmer.

\subsection{Household Size}

The size of the Household is a driver for the adoption and implementation of any given adaptation practice, since the number of people living in a household influence the labour as an input for farm production, especially manual farm labour, like in the adoption of Soil and Water Conservation practices.

\subsection{Change in Planting Date}

Planting dates from seasonal calendars affect the implementation of adaptation practices due to growth time and maturity time. However this is specific to different crops in the study area, especially to annuals (maize, beans, and among others) and perennial crops like coffee and Banaana. This is very particular across seasons of farmer calendar years due to rainfall variability in the study area.

\subsection{Drought Shock}

The drought occurrence influences the adoption of crop varieties, mulching of annual crops like Maize and perennials, like Banana and Coffee, with a view to providing a moisture retention benefit to the crops. This is a major driver across gender, farmer experience, landscape position, flood prone areas like low lands, and all other forms of adaptation practices that are implemented in the study area.

\subsection{Adoption of Tree Planting/or Agroforestry}

The adoption of agroforestry and tree planting, especially leguminous trees, in the study area are very influential among farmers regardless of gender, experience in farming, Landscape position and any other practices. Farmers increasingly use agroforestry as a land use system to conserve soils and moderate the climate, specifically in their gardens and farms. According to field observations conducted during the study, this practice is increasingly implemented in the upper slopes of the Rwenzori Mountain slopes especially across banana and coffee cropping systems. 


\section{Conclusions}

The study investigated the determinants and factors for the adoption of adaptation practices using survey data obtained from the farming communities in the Albertine region of southwestern Uganda. Farmers' responses indicated that they perceive a change in the amount of annual/seasonal (900 mm-1600 mm) rainfall received over the period since 1980. They based their perceptions on changes in the seasons and occurrences of rainfall for the last 30 years (1980-2009). Those who could afford to practice adaptation on their farms were able to point to the implementation of soil conservation practices, Use of crop varieties, changing plant calendar dates, planting trees/agroforestry, and furrow irrigation on their farms, in their various attempts to adapt to climate change impacts. However, different barriers were also highlighted that hinder adoption of climate change adaptation practices, including lack of information, lack of finance, shortage of labor, and poor irrigation facilities.

The results from the marginal analysis using the Multinomial Logistic regression model (MNL) indicated that characteristics, such as a number of years of farming experience, household size, landscape position (upper, middle, lower slopes), crop yield and farm income, land size, and farm income play a determining role in adaptation. These could be further prioritized through policy and strategic development plans, as proposed interventions to influence adoption of climate change adaptation practices by encouraging small holder farmers through agriculture extension programs and community farmer organisations to cultivate crops that are suitable in the landscape positions where their lived and farming experience could be used as an asset to complement the extension programs at a community level through senstisation. The influence of smallholder farmer to adaptation choices and level of implementation could be subjected to further research into ameliorating the negative impacts of climate changes. All of the explanatory variables included in the model (sex, age, the experience of farming, household size, membership, shock floods, shock drought, land size, results of shock, use inputs, landscape position, education (formal schooling, crop yield, farm income, among others) have been fundamental in implementing adaptation practices. Although climate change adaptations varied with landscape position and agro-ecological conditions, it was found that the availability of farm inputs and credit facilities in particular would increase the likelihood of the adaptation of practices, such as the use of improved crop varieties, soil conservation, planting trees and agroforestry, and the adoption of irrigation.

Also, climate variability, and specifically an increase in temperature, are among the drivers for farmers' moves to adopt different adaptation practices that could buffer climate risks affecting the crop productivity, including practices like soil conservation, crop varieties, changing plant calendar dates/or agroforestry, and furrow irrigation to cope with changes and variability in climate. All of these practices could enhance agricultural productivity (by $5-10 \%$ yield increase) if farmers are supported with investments in these practices.

Finally, climate change adaptation by smallholder farmers and its determinants for adoption by farming communities and development intervention continues to be a very important focus for research and development. Prioritising the implementation of adaptation choices based on small holder farmer socio-economic characteristics is instrumental in improving agriculture productivity and livelihoods by the government and other development partners. This will result into effective planning and the efficient use of government resources to boost agriculture productivity, improve crop yields, and increase household farm income and investments in climate change adaptation. Understanding the key determinants for adaptation within a smallholder farm context will facilitate and encourage the adoption of improved crop varieties, appropriate distribution of furrow irrigation, and implementation of Soil Water and conservation measures a key to ensuring food security in smallholder agriculture.

Acknowledgments: This research was supported by funding from the Department for International Development (DfID) under the Climate Impact Research Capacity and Leadership Enhancement (CIRCLE) program. The authors are grateful to this funding support and we convey our regards to the Host Institution, the Centre for Climate Change Studies, University of Dar es Salaam, Makerere University, African Academy of Sciences and Association 
of Commonwealth Universities for continued support towards fostering capacity development in climate change across Africa.

Author Contributions: Alex Zizinga conducted the study and wrote the original draft under supervision of Richard Y. M. Kangalawe, Andrew Ainslie contributed to the write up and edited the language manuscript all the time, Moses M. Tenywa made an input in the literature, Jackson Majaliwa provided an input in the methods and continuous guidance on the statistics. Naome Jones Saronga and Esther E. Amoako participated in the discussions during the study design in Tanzania.

Conflicts of Interest: The authors declare no conflicts of interest.

\section{References}

1. Bojinski, S.; Verstraete, M.; Peterson, T.C.; Richter, C.; Simmons, A.; Zemp, M. The concept of essential climate variables in support of climate research, applications, and policy. Bull. Am. Meteorol. Soc. 2014, 95, 1431-1443. [CrossRef]

2. Hisali, E.; Birungi, P.; Buyinza, F. Adaptation to climate change in Uganda: Evidence from micro level data. Glob. Environ. Chang. 2011, 21, 1245-1261. [CrossRef]

3. Lobell, D.B.; Burke, M.B.; Tebaldi, C.; Mastrandrea, M.D.; Falcon, W.P.; Naylor, R.L. Prioritizing climate change adaptation needs for food security in 2030. Science 2008, 319, 607-610. [CrossRef] [PubMed]

4. Parry, M.L. Climate Change 2007-Impacts, Adaptation and Vulnerability: Working Group II Contribution to the Fourth Assessment Report of the IPCC; Cambridge University Press: Cambridge, UK, 2007.

5. Below, T.; Artner, A.; Siebert, R.; Sieber, S. Micro-Level Practices to Adapt to Climate Change for African Small-Scale Farmers. A Review of Selected Literature; Environment and Production Technology Division: Wahsington, DC, USA, 2010; p. 953.

6. Below, T.B.; Mutabazi, K.D.; Kirschke, D.; Franke, C.; Sieber, S.; Siebert, R.; Tscherning, K. Can farmers' adaptation to climate change be explained by socio-economic household-level variables? Glob. Environ. Chang. 2012, 22, 223-235. [CrossRef]

7. Pearce, D.W.; Cline, W.R.; Achanta, A.N.; Fankhauser, S.; Pachauri, R.K.; Tol, R.S.; Vellinga, P. The social costs of climate change: Greenhouse damage and the benefits of control. In Climate Change 1995: Economic and Social Dimensions of Climate Change; Cambridge University Press: Cambridge, UK, 1996; pp. 179-224.

8. Easterling, D.R.; Meehl, G.A.; Parmesan, C.; Changnon, S.A.; Karl, T.R.; Mearns, L.O. Climate extremes: Observations, modeling, and impacts. Science 2000, 289, 2068-2074. [CrossRef] [PubMed]

9. Soloman, S.; Qin, D.; Manning, M.; Marquis, M.; Averyt, K.; Tignor, M.; Miller, H.L. IPCC-Intergovernmental Panel on Climate Change. In Climate Change 2007: The Physical Science Basis; Cambridge University Press: Cambridge, UK, 2007.

10. Howden, M.; Soussana, J.F.; Tubiello, F.; Chhetri, N.; Dunlop, M.; Meinke, H. Adapting agriculture to climate change. Proc. Natl. Acad. Sci. USA 2007, 104, 19691-19696. [CrossRef] [PubMed]

11. Ainsworth, E.A.; Ort, D.R. How do we improve crop production in a warming world? Plant Physiol. 2010, 154, 526-530. [CrossRef] [PubMed]

12. Rosegrant, M.W.; Cline, S.A. Global food security: Challenges and policies. Science 2003, 302, 1917-1919. [CrossRef] [PubMed]

13. Parry, M.L.; Rosenzweig, C.; Iglesias, A.; Livermore, M.; Fischer, G. Effects of climate change on global food production under SRES emissions and socio-economic scenarios. Glob. Environ. Chang. 2004, 14, $53-67$. [CrossRef]

14. Schmidhuber, J.; Tubiello, F.N. Global food security under climate change. Proc. Natl. Acad. Sci. USA 2007, 104, 19703-19708. [CrossRef] [PubMed]

15. Majaliwa, J.; Omondi, P.; Komutunga, E.; Aribo, L.; Isubikalu, P.; Tenywa, M.M.; Massa-Makuma, H. Regional climate model performance and prediction of seasonal rainfall and surface temperature of Uganda. Afr. Crop Sci. J. 2012, 20, 213-225.

16. Uganda Bureau of Statistics: 2014 Statistical Abstract. Available online: http:/ /www.ubos.org/onlinefiles / uploads/ubos/statistical_abstracts/Statistical_Abstract_2014.pdf (accessed on 30 November 2017).

17. Hardee, K.; Mutunga, C. Strengthening the link between climate change adaptation and national development plans: Lessons from the case of population in National Adaptation Programmes of Action (NAPAs). Mitig. Adapt. Strateg. Glob. Chang. 2010, 15, 113-126. [CrossRef] 
18. Zizinga, A. Viability Analysis of Climate Change Adaptation and Coping Practices for Agriculture Productivity in Rwenzori Region, Kasese District; Makerere University: Kampala, Uganda, 2013.

19. Kraybill, D.; Kidoido, M. Analysis of Relative Profitability of Key Ugandan Agricultural Enterprises by Agricultural Production Zone; International Food Policy Research Institute (IFPRI): Washington, DC, USA, 2009.

20. Almeida, J.P.; Montúfar, R.; Anthelme, F. Patterns and origin of intraspecific functional variability in a tropical alpine species along an altitudinal gradient. Plant Ecol. Divers. 2013, 6, 423-433. [CrossRef]

21. Challinor, A.J.; Ewert, F.; Arnold, S.; Simelton, E.; Fraser, E. Crops and climate change: Progress, trends, and challenges in simulating impacts and informing adaptation. J. Exp. Bot. 2009, 60, 2775-2789. [CrossRef] [PubMed]

22. Nhemachena, C.; Hassan, R. Micro-Level Analysis of Farmers' Adaptation to Climate Change in Southern Africa; Environment and Production Technology Division, IFPRI: Washington, DC, USA, 2007.

23. Cooper, P.J.; Cappiello, S.; Vermeulen, S.J.; Campbell, B.M.; Zougmoré, R.; Kinyangi, J. Large-Scale Implementation of Adaptation and Mitigation Actions in Agriculture; CCAFS: Wageningen, The Netherlands, 2013.

24. Deressa, T.T.; Hassan, R.M.; Ringler, C.; Alemu, T.; Yesuf, M. Determinants of farmers' choice of adaptation methods to climate change in the Nile Basin of Ethiopia. Glob. Environ. Chang. 2009, 19, 248-255. [CrossRef]

25. Arjan, R.; Mark, B.; Minna, K.; Vincent, L.; Nico, P. Adapting to Climate Variability: Learning from Past Experience and the Role of Institutions; The World Bank: Washington, DC, USA, 2011.

26. Nabikolo, B.; Bashaasha, B.; Mangheni, M.N.; Majaliwa, J.G.M. Determinant of climate change adaptation among male and female headed households in eastern Uganda. Afr. Crop Sci. J. 2012, 20, 203-212.

27. IPCC, TAR. Climate Change 2001: Impacts, Adaptation and Vulnerability; IPCC Third Assessment Report; Cambridge University Press: New York, NY, USA, 2001.

28. Yamane, T. Statistics, an Introductory Analysis, 2nd ed.; Harper and Row: New York, NY, USA, 1967.

29. Israel, G.D. Sampling the Evidence of Extension Program Impact: Citeseer; University of Florida: Gainesville, FL, USA, 1992.

30. Panda, A.; Sharma, U.; Ninan, K.; Patt, A. Adaptive capacity contributing to improved agricultural productivity at the household level: Empirical findings highlighting the importance of crop insurance. Glob. Environ. Chang. 2013, 23, 782-790. [CrossRef]

31. Hassan, R.; Nhemachena, C. Determinants of African farmers' strategies for adapting to climate change: Multinomial choice analysis. Afr. J. Agric. Resour. Econ. 2008, 2, 83-104.

32. Kurukulasuriya, P.; Mendelsohn, R. Crop switching as a strategy for adapting to climate change. Afr. J. Agric. Resour. Econ. 2008, 2, 105-126.

33. Seo, S.N.; Mendelsohn, R. An analysis of crop choice: Adapting to climate change in South American farms. Ecol. Econ. 2008, 67, 109-116. [CrossRef]

34. Deressa, T.; Hassan, R.; Ringler, C. Perception of and adaptation to climate change by farmers in the Nile basin of Ethiopia. J. Agric. Sci. 2011, 149, 23-31. [CrossRef]

35. Yibekal, T.; Chanyalew, A.; Getachew, E. Understanding the process of adaptation to climate change by small-holder farmers: The case of east Hararghe Zone, Ethiopia. Agric. Food Econ. 2014, 1, 1-13.

36. Atinkut, B.; Mebrat, A. Determinants of farmers choice of adaptation to climate variability in Dera woreda, south Gondar zone, Ethiopia. Environ. Syst. Res. 2016, 5, 6. [CrossRef]

37. Fatuase, A.; Ajibefun, A. Adaptation to climate change: A case study of rural farming households' in Ekiti State, Nigeria. In Proceedings of the International Conference on Climate Change Effects (Impacts World 2013), Potsdam, Germany, 27-30 May 2013.

38. Kangalawe, R.Y. Changing Land-Use Patterns in the Irangi Hills, Central Tanzania: A Study of Soil Degradation and Adaptive Farming Strategies. Ph.D. Thesis, Department of Physical Geography and Quaternary Geology, Stockholm University, Stockholm, Sweden, 2001.

39. Lobell, D.B.; Field, C. Global scale climate-crop yield relationships and the impacts of recent warming. Environ. Res. Lett. 2007, 2, 014002. [CrossRef]

40. Lynn, S.R. Economic Development: Theory and Practice for a Divided World; Pearson College Division: London, UK, 2003.

41. Teshome, A.; Rolker, D.; de Graaff, J. Financial viability of soil and water conservation technologies in northwestern Ethiopian highlands. Appl. Geogr. 2013, 37, 139-149. [CrossRef]

42. Tenge, A.J.M. Participatory Appraisal for Farm-Level Soil and Water Conservation Planning in West Usambara Highlands, Tanzani; Wageningen University: Wageningen, The Netherlands, 2005. 
43. Herweg, K.; Ludi, E. The performance of selected soil and water conservation measures-Case studies from Ethiopia and Eritrea. Catena 1999, 36, 99-114. [CrossRef]

44. Pattanayak, S.K.; Mercer, D.E.; Sills, E.; Yang, J.-C. Taking stock of agroforestry adoption studies. Agrofor. Syst. 2003, 57, 173-186. [CrossRef]

45. Blanco-Canqui, H.; Lal, R. No-tillage and soil-profile carbon sequestration: An on-farm assessment. Soil Sci. Soc. Am. J. 2008, 72, 693-701. [CrossRef]

46. McIntyre, B.D.; Riha, S.J.; Ong, C.K. Competition for water in a hedge-intercrop system. Field Crop. Res. 1997, 52, 151-160. [CrossRef]

47. Young, J.S.; Knezek, P.M. The ratio of molecular to atomic gas in spiral galaxies as a function of morphological type. Astrophys. J. 1989, 347, L55-L58. [CrossRef]

48. Szott, L.T.; Palm, C.A.; Buresh, R.J. Ecosystem fertility and fallow function in the humid and subhumid tropics. Agrofor. Syst. 1999, 47, 163-196. [CrossRef]

(C) 2017 by the authors. Licensee MDPI, Basel, Switzerland. This article is an open access article distributed under the terms and conditions of the Creative Commons Attribution (CC BY) license (http:/ / creativecommons.org/licenses/by/4.0/). 